\title{
Carryover of aflatoxin from feed to milk in dairy cows with low or high somatic cell counts
}

\author{
F. Masoero ${ }^{1+}$, A. Gallo ${ }^{1}$, M. Moschini ${ }^{1}$, G. Piva ${ }^{1}$ and D. Diaz ${ }^{2}$ \\ ${ }^{1}$ Istituto di Scienze degli Alimenti e della Nutrizione, Facoltà di Agraria, Università Cattolica del Sacro Cuore, Via Emilia Parmense 84, 29100 Piacenza, Italy; \\ ${ }^{2}$ Department of Animal Dairy and Veterinary Sciences, Utah State University, Logan, UT 84322-4815, USA
}

(Received 18 January 2007; Accepted 2 July 2007)

\begin{abstract}
Aflatoxin M1 (AFM1) residues in milk are regulated in many parts of the world and can cost dairy farmers significantly due to lost milk sales. Additionally, due to the carcinogenicity of this compound contaminated milk can be a major public health concern. Thirty-four lactating dairy cows were utilised to investigate the relationship between somatic cell counts (SCC), milk yield and conversion of dietary aflatoxin B1 (AFB1) into milk AFM1 (carryover (CO)). The AFM1 in milk increased as soon as the first milking after animal ingestion with a pattern of increment up to the observed plateau (between 7th and 12th days of AFB1 ingestion). There was a significant $(\mathrm{P}<0.01)$ effect of the milk yield whereas no effect could be attributed to the SCC levels or to the milk yield $\times$ SCC interaction. Similarly, the main effect of milk yield was also observed $(\mathrm{P}<0.01)$ on the total amount of AFM1 excreted during the ingestion period. Although the plasma concentration of gamma-glutamyl transferase was significantly affected by aflatoxin administration, levels of this liver enzyme were within the normal range for lactating dairy cows. The current data suggest that milk yield is the major factor affecting the total excretion of AFM1 and that SCC as an indicator of mammary gland permeability was not related to an increase in AFM1 CO.
\end{abstract}

Keywords: aflatoxins, aflatoxin M1, dairy cows, milk, somatic cell count

\section{Introduction}

The aflatoxins are secondary metabolites produced primarily by Aspergillus flavus and $A$. parasiticus. Aflatoxins are common crop contaminants, with contamination occurring in the field, during harvest or during storage. The most frequently affected crops are maize (Zea mais), cotton and peanuts and their by-products. The major aflatoxins are aflatoxin B1 (AFB1), B2, G1 and G2. Because of their low molecular weight, once ingested these compounds are rapidly adsorbed in the gastro-intestinal tract through a non-described passive mechanism (Yiannikouris and Jouany, 2002) and quickly appear as a metabolite in blood after just 15 min (Moschini et al., 2006) and in milk as soon as $12 \mathrm{~h}$ post-feeding (Diaz et al., 2004).

Aflatoxin M1 (AFM1) is the principal oxidised metabolite of AFB1 and can be readily found in the milk and urine of most mammalians after consumption of AFB1. The aflatoxins, as a group (AFB1, AFB2, AFG1, AFG2 and AFM1), are classified as group 1 carcinogens (International Agency

${ }^{\dagger}$ E-mail: francesco.masoero@unicatt.it for Research on Cancer, 2002). The European Union allowable limits for AFB1 in animal feeds and concentrates are 20 and $5 \mu \mathrm{g} / \mathrm{kg}$, respectively (European Community, 2003). Furthermore, the European Community (EC) limits AFM1 in milk to levels not greater than $0.05 \mu \mathrm{g} / \mathrm{l}$ (European Community, 2006). In the US, AFM1 is regulated by the US Food and Drug Administration (FDA) at $0.5 \mu \mathrm{g} / \mathrm{l}$.

In dairy cows the amount of AFM1 excreted into milk can be up to $3 \%$ of the AFB1 intake (Diaz et al., 2004) and is affected by milk yield (Pettersson et al., 1989; Veldman et al., 1992) and stage of lactation (Munksgaard et al., 1987; Pettersson et al., 1989; Veldman et al., 1992). Other factors that affect carryover (CO) into milk include species differences (Battacone et al., 2003), animal variability (Van Egmond, 1989; Steiner et al., 1990; Veldman et al., 1992) and mammary alveolar cell membrane health (Lafont et al., 1983).

There is limited information about the effect of udder infection on AFM1 excretion into milk. It has been suggested that an increase in AFM1 CO occurs due to Staphylococcus udder infection (Veldman et al., 1992) whereas a previous study showed a relationship between AFM1 milk $\mathrm{CO}$ and milk somatic cell counts (SCC) independent of the 
milk yield (Lafont et al., 1983). Mastitis increases the number of somatic cells in milk, alters milk composition (Walstra and Jenness, 1984) and may affect AFM1 CO rate by increasing membrane permeability.

The objective of this work was to evaluate the effect of milk yield and SCC, as indicators of udder inflammatory processes, on milk AFM1 CO in lactating dairy cows.

\section{Material and methods}

\section{Animals and treatments}

An experiment was carried out utilising 34 Holstein multiparous cows housed at the CERZOO research and experimental centre (San Bonico, PC, Italy). The research protocol and animal care were in accordance with the EC Council Directive guidelines for animals used for experimental and other scientific purposes (European Community, 1986).

Milk yield and SCC data for classification of animals as high or low were obtained as the average of three measurements during a 15-day pre-experimental period. Individual milk yield for the factorial arrangement was measured daily during the last week of the pre-experimental period. Milk yield (LY: $<30 \mathrm{~kg}$ per head per day; HY: $>30 \mathrm{~kg}$ per head per day) and milk SCC (LSCC: < $350000 ;$ HSCC: $>350000)$ were used in a $2 \times 2$ factorial arrangement in a completely randomised design.

Cows were housed in a free stall barn and had free access to water. The diet was formulated according to the nutrient requirements of dairy cattle (National Research Council, 2001) for an average cow weighing $600 \mathrm{~kg}, 140$ days in milk and a $35 \mathrm{~kg}$ milk yield (3.8\% fat and $3.35 \%$ protein). The bulk of the diet (Table 1) on a dry-matter basis was maize silage $(31.2 \%)$, dehydrated alfalfa hay $(16.7 \%)$, grass hay $(4.1 \%)$ and energy-protein supplement $(48 \%)$. The diet was fed ad libitum (5\% expected orts) as a total mixed ration (TMR) daily $(0900 \mathrm{~h})$. Cows were milked twice a day (0230 and $1330 \mathrm{~h}$ ) and individual milk yield was recorded at every milking (Afimilk system, Afikim, Israel).

During the experimental period (10 days), cows were given, before the morning meal, a $300 \mathrm{~g}$ bolus containing $1.004 \pm 0.03 \mathrm{~g}$ per cow per day of a naturally contaminated corn meal. This allowed for an AFB1 intake from the contaminated bolus of $98.10 \pm 0.26 \mu \mathrm{g}$ per cow per day.

TMR samples were collected on days 0 and 10 of the experimental period, dried at $55^{\circ} \mathrm{C}$ in a ventilated oven until constant weight, and then ground with a 1-mm sieve (Thomas-Wiley Laboratory Mill, Arthur H. Thomas Co., Philadelphia, PA, USA) and frozen until aflatoxin analysis.

Individual milk samples were collected at each milking for 18 consecutive days (during the last 2 days of the pre-experimental period, the experimental period (10 days) and for 6 days at the end of the AFB1 ingestion period); then a representative sample for day of milking was obtained and stored at $-18^{\circ} \mathrm{C}$ for subsequent analysis. Milk samples collected at days 3,7 and 10 of the treatment
Table 1 Ingredients and chemical composition of the basal diet

Base diet

\begin{tabular}{lr}
\hline Ingredients (g/kg dry matter (DM)) & \\
Maize silage & 312 \\
Alfalfa hay, dehydrate & 167 \\
Grass hay & 41 \\
Cotton seed, whole with lint & 85 \\
Maize meal & 183 \\
Barley meal & 66 \\
Protein supplement ${ }^{\dagger}$ & 103 \\
Calcium soap (Megalac) & 9 \\
Soya-bean meal & 34 \\
& \\
Chemical composition (g/kg DM) & \\
Crude protein & 162 \\
Crude lipids & 49 \\
ADF $^{\ddagger}$ & 204 \\
NDF $^{\ddagger}$ & 340 \\
& \\
Calculated & \\
PeNDF & \\
NSC $^{\S}$ & Forage (\%) \\
Net energy lactation (MJ/kg DM) & \\
\hline \hline
\end{tabular}

${ }^{\dagger}$ Contains per $\mathrm{kg}$ of pre-mix: soya-bean meal $600 \mathrm{~g}$, sunflower meal $300 \mathrm{~g}$, mineral and vitamin supplement $100 \mathrm{~g} ; 120000 \mathrm{IU}$ of vitamin $\mathrm{A} ; 9000 \mathrm{IU}$ of vitamin $D_{3} ; 90 \mathrm{mg}$ of vitamin $\mathrm{E}_{;} 3.6 \mathrm{mg}$ of $\mathrm{Co}_{0} ; 19.2 \mathrm{mg}$ of I; $1.44 \mathrm{mg}$ of $\mathrm{Se}$; $600 \mathrm{mg}$ of $\mathrm{Mn} ; 62.4 \mathrm{mg}$ of $\mathrm{Cu} ; 2240 \mathrm{mg}$ of $\mathrm{Zn} ; 1.92 \mathrm{mg}$ of $\mathrm{Mo} ; 360 \mathrm{mg}$ of $\mathrm{Fe}$.

${ }^{\ddagger} \mathrm{ADF}=$ acid-detergent fibre expressed without residual ash. NDF $=$ neutraldetergent fibre according to Van Soest et al. (1991) without sodium sulphite and with alpha-amylase; expressed without residual ash.

\$PeNDF = physical effective neutral-detergent fibre (Mertens, 1997), calculated according to the contribution of the single feed present into the diet (concentrates were considered with $\mathrm{PeNDF}=0$; whole cotton seeds PeNDF $=70)$. NSC was calculated as $\mathrm{NSC}=100-(\mathrm{NDF}+\mathrm{ASH}+$ crude protein + crude lipids).

According to NRC (2001).

period were analysed for fat, protein and lactose contents (infrared analysis, Milkoscan Model FT120 Foss Electric, Hillerod, Denmark) and for SCC (Fossomatic 360 Foss Electric, Hillerod, Denmark).

\section{Sample analysis}

AFB1 assay in feeds. Ten grams of dried feed were put in a methanol: water solution $(80: 20 \mathrm{vol} / \mathrm{vol})$, shaken at 150 r.p.m. for $45 \mathrm{~min}$ (Universal Table Shaker 709) and filtered with Schleicher \& Schuell 595 1 12 filter paper (Dassel, Germany). Then, $5 \mathrm{ml}$ were eluted with $45 \mathrm{ml}$ of bidistilled water through an immunoaffinity column (Aflatoxin Easiextract, Rhône Diagnostics Technologies, Glasgow, UK) previously washed with $20 \mathrm{ml}$ of a phosphate-buffered saline solution ( $\mathrm{pH}$ 7.4). The column was washed with $5 \mathrm{ml}$ water and slowly eluted with $2.5 \mathrm{ml}$ of methanol. The extract was dried under nitrogen, redissolved in $1 \mathrm{ml}$ acetonitrile : water $(25: 75)$ solution and filtered (Millipore Corporation, Bedford, MA, USA; HV $0.45 \mu \mathrm{m}$ ) before HPLC analysis. 
AFM1 assay in milk samples. Extraction was carried out by the immunoaffinity technique, according to Mortimer et al. (1987). Briefly, $50 \mathrm{ml}$ of defatted milk (centrifuged at 7000 r.p.m. for $10 \mathrm{~min}$ at $4^{\circ} \mathrm{C}$ ) were filtered with Schleicher \& Schuell 595 1 1 2 filter paper (Dassel, Germany). Then, $20 \mathrm{ml}$ were passed through an immunoaffinity column (Aflatoxin Easy-extract, Rhône Diagnostics Technologies, Glasgow, UK) previously washed with $20 \mathrm{ml}$ of a phosphate-buffered saline solution $(\mathrm{pH} 7.4)$. The column was washed with $5 \mathrm{ml}$ water, and slowly eluted with $2.5 \mathrm{ml}$ of methanol. The extract was dried under nitrogen, redissolved in $1 \mathrm{ml}$ acetonitrile: water (25:75) solution and filtered (Millipore Corporation, Bedford, MA, USA; HV $0.45 \mu \mathrm{m}$ ) before HPLC analysis.

\section{Chromatography}

The HPLC analysis was performed by a Perkin Elmer LC (Perkin Elmer, Norwalk, CT, USA) equipped with an LC-200 pump and a Jasco FP-1520 fluorescence detector (Jasco, Tokyo, Japan). The system and data acquisition were controlled by Jasco Borwin Chromatography PC software.

The AFB1 was separated with a reverse-phase C18 Superspher column $(4 \mu \mathrm{m}$ particle size, $125 \times 4 \mathrm{~mm}$ i.d.; Merck, Darmstadt, Germany) at room temperature and isocratic conditions, with a mobile phase of water and acetonitrile:methanol solution $(17: 29, \mathrm{vol} / \mathrm{vol})$ with a $64: 36$ (vol/vol) ratio. The flow rate was $1 \mathrm{ml} / \mathrm{min}$. Then, the AFB1 was detected by fluorescence, after post-column dramatisation (Jasco 2080 Plus HPLC pump) with pyridinium hydrobromide perbromide (PBPB) at a flow of $0.1 \mathrm{ml} / \mathrm{min}$. The fluorescence detector was set at $365 \mathrm{~nm}$ excitation and $440 \mathrm{~nm}$ emission wavelengths. The standard stock solution was checked for AFB1 concentration according to AOAC method 970.44 (Association of Official Analytical Chemists (AOAC), 1995) and stored at $-20^{\circ} \mathrm{C}$ when not in use.

The AFM1 was separated with a reverse-phase C18 LiChospher 100 column (Merck, Darmstadt, Germany; $5 \mu \mathrm{m}$ particle size, $125 \times 4 \mathrm{~mm}$ i.d.) at room temperature, with a water and acetonitrile $(75: 25 \mathrm{vol} / \mathrm{vol})$ mobile phase and the flow rate set at $1 \mathrm{ml} / \mathrm{min}$. The fluorescence detector was set at $365 \mathrm{~nm}$ excitation and $440 \mathrm{~nm}$ emission wavelengths. The standard stock solution was checked for AFM1 concentration according to AOAC method 970.44 (AOAC, 1995) and stored at $-20^{\circ} \mathrm{C}$ when not in use.

\section{Blood samples}

Blood samples were taken before the morning meal via jugular venipuncture on days 0 and 10 of the experimental period. The blood was collected into Li-heparinised (17 U of heparin per $\mathrm{ml}$ of blood) Vacutainer (Vacutainer systems, Belliver industrial estate, Plymouth, UK). Then, plasma was obtained by centrifugation (3000 r.p.m. for $15 \mathrm{~min}$ ). The plasma fraction was isolated and stored at $-20^{\circ} \mathrm{C}$ until analysed for albumin, globulin, aspartate aminotransferase, gamma-glutamyl transferase and bilirubin and beta-hydroxybutyrate concentrations (Bertoni, 1999).

\section{CO calculation}

The $\mathrm{CO}$ of AFM1 in milk was calculated as the percentage of the AFB1 consumed that was excreted as AFM1 in milk at the time when the toxin output in milk reached a steady state.

\section{Statistical analyses}

The AFB1 intake, AFM1 milk concentration, and total excretion and the $\mathrm{CO}$ in milk were analysed using the mixed procedure of $S A S^{\circledR}$ (Statistical Analysis System Institute, 2001). A factorial arrangement was used, and fixed effect in the model included the milk yield and the milk SCC. The animal, within-milk yield, and SSC interactions were included as random effects. The day of collection was a repeated measure (compound symmetry covariance structure).

The CO (\%) was regressed on milk yield $(\mathrm{kg})$ over time of collection (day) and the linear equation was calculated.

Plasma parameters (pre-experimental and after AFB1 ingestion period) were compared using the paired $t$-test (Statistical Analysis System Institute, 2001).

\section{Results}

As expected, the low AFB1 concentration fed to animals did not cause negative health problems during the experimental period. The initial milk yield and the milk SCC for groups were (mean \pm s.d.) $21.2 \pm 3.8$ and $127600 \pm$ $161203,21.7 \pm 3.9$ and $1171889 \pm 676859,41.8 \pm 8.4$ and $240000 \pm 20075$, and $34.8 \pm 4.6$ and 2030667 \pm 2451 213, respectively, for LY-LSCC, LY-HSCC, HY-LSCC and HY-HSCC.

The TMR had a base AFB1 content of $3.70 \pm 0.21 \mu \mathrm{g} / \mathrm{kg}$ contributing to a bulk milk AFM1 content of $4.80 \pm 1.80$ and $3.90 \pm 1.72 \mathrm{ng} / \mathrm{l}$, respectively, before and after the ingestion period.

The AFM1 in milk increased as soon as the first milking after animal ingestion with a pattern of increment up to the observed plateau (between the 7th and 12th days of ingestion) as reported in Figure 1. At day 1 of AFB1 ingestion, the AFM1 contents in milk were 52.9 v. 24.9 and 44.0 v. $39.3 \mathrm{ng} / \mathrm{l}$, respectively, for the HY-HSCC, HY-LSCC, LY-HSCC and LY-LSCC groups. Closer values among groups were observed from the 3rd day until the end of the ingestion period with average AFM1 contents at the plateau conditions of $65.8,61.9,66.7$ and $59.2 \mathrm{ng} / \mathrm{l}$ respectively for the HY-HSCC, HY-LSCC, LY-HSCC and LY-LSCC groups (Table 2).

The AFB1 CO into milk calculated at the plateau was $2.32,2.70,1.48$ and $1.29 \%$ of the AFB1 consumed, respectively, for the HY-HSCC, HY-LSCC, LY-HSCC and LYLSCC groups. There was a significant $(P<0.01)$ effect of 
the milk yield whereas no effect could be attributed to the somatic cell count level or to the milk yield $\times$ somatic cell count interaction. Similarly, the main effect of milk was also observed $(P<0.01)$ on the total amount of AFM1 excreted during the AFB1 ingestion period.

Plasma biochemistry for samples collected before and after the aflatoxin ingestion period are reported in Table 3.

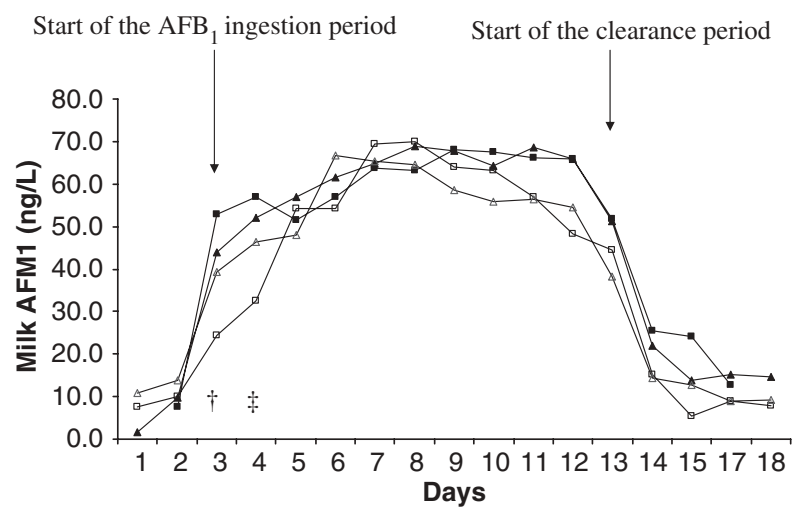

Figure 1 AFM1 concentration in the milk of cows from different factorial

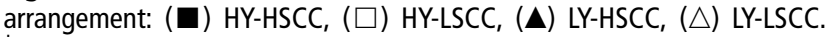
${ }^{+}$Somatic cells count effect $(P<0.01)$. Production and somatic cells count interaction effect sliced for the level of production significant $(P<0.01)$ in the HY group. ${ }^{\ddagger}$ Somatic cells count effect $(P<0.05)$. Production and somatic cells count interaction effect sliced for the level of production significant $(P<0.05)$ in the HY group.

\section{Discussion}

The presence of AFM1 in milk was detectable from the first milking after the animal AFB1 ingestion (Figure 1), which is in accordance with previous work (Allcroft et al., 1968; Trucksess et al., 1983; Diaz et al., 2004). In particular, in the early stage of increase of the AFM1 plateau (between the 7th and 12th days of ingestion) there was an effect $(P<0.01)$ of the SCC. However, the SCC effect was confined to the high-yield groups $(P<0.01$ and $P<0.05$, respectively, for the 1 st and 2 nd day of ingestion) due to the milk yield and SCC interaction being separated from the level of production (Figure 1). Results suggest that high milk yield could intensify the effect of SCC on AFM1 CO. A previous report suggested a positive correlation between SCC and milk AFM1 content in dairy cows fed an AFB1contaminated diet (Lafont et al., 1983). However, these authors did not report the effect of milk yield in their study.

The observed plateau developed later than in previous studies, in which the steady state for AFM1 was established at 24 (Frobish et al., 1986) and 76 h (Polan et al., 1974, Diaz et al., 2004) from the initial AFB1 ingestion, but is in agreement with results reported by Battacone et al. (2003) on sheep, in which the observed plateau condition was between day 9 and day 13 from the first AFB1 ingestion. However, milk AFM1 levels in the present study were lower than previously reported maximum concentrations. Previous studies with dairy cows report a plateau at maximum AFM1 concentrations in milk (Polan et al., 1974; Frobish et al., 1986; Pettersson et al., 1989).

Table 2 AFB1 intake $(\mu \mathrm{g})$, AFM1 milk concentration ( $\mathrm{ng} / \mathrm{l})$ and total excretion ( $\mu \mathrm{g}$ per cow per day) and carryover (\%) at plateau (7th to 12th day on AFB1 ingestion)

\begin{tabular}{|c|c|c|c|c|c|c|c|c|}
\hline \multirow[b]{2}{*}{ Item } & \multicolumn{4}{|c|}{ Groups } & \multirow[b]{2}{*}{ s.e. } & \multicolumn{3}{|c|}{ Main effects $(P<)$} \\
\hline & HY-HSCC & HY-LSCC & LY-HSCC & LY-LSCC & & Milk yield & SCC & Milk yield $\times \mathrm{SCC}$ \\
\hline AFB1 intake $(\mu \mathrm{g})$ & 98.0 & 98.3 & 98.0 & 98.1 & 0.064 & 0.455 & 0.007 & 0.141 \\
\hline AFM1 (ng/l) & 65.8 & 61.9 & 66.7 & 59.2 & 4.908 & 0.915 & 0.500 & 0.832 \\
\hline Total AFM1 excreted ( $\mu \mathrm{g}$ per cow per day) & 2.27 & 2.66 & 1.45 & 1.27 & 0.177 & 0.001 & 0.756 & 0.360 \\
\hline Carryover (\%) & 2.32 & 2.70 & 1.48 & 1.29 & 0.180 & 0.001 & 0.767 & 0.366 \\
\hline
\end{tabular}

Table 3 Blood parameters for cows with low somatic cell counts (LY-LSCC and HY-LSCC) before and after AFB1 ingestion ${ }^{+}$

\begin{tabular}{lccccc}
\hline \hline Parameter & Before ingestion & After ingestion & s.e. & $P^{\ddagger}$ & Range $^{\S}$ \\
\hline Albumin $(\mathrm{g} / \mathrm{l})$ & 33.75 & 37.50 & 0.871 & 0.0012 & $32.3-35.9$ \\
Globulin $(\mathrm{g} / \mathrm{l})$ & 33.83 & 38.50 & 1.469 & 0.0088 & $38.3-57.6$ \\
Aspartate aminotrasnferase (U/l) & 63.17 & 68.25 & 3.903 & 0.2194 & $61.1-103$ \\
Gamma-glutamyl transferase (U/l) & 26.58 & 29.58 & 0.739 & 0.0019 & $20.8-45.1$ \\
Bilirubin ( $\mu$ mol/l) & 2.78 & 2.56 & 0.272 & 0.4261 & $1.63-4.58$ \\
Beta-hydroxybutyrate (mmol/l) & 0.51 & 0.46 & 0.082 & 0.5357 & $0.16-0.75$ \\
\hline \hline
\end{tabular}

${ }^{+}$Cows consuming a $300 \mathrm{~g}$ bolus containing $1.004 \pm 0.03 \mathrm{~g}$ per cow per day of a naturally contaminated maize meal. This allowed for an AFB1 intake from the contaminated bolus of $98.10 \pm 0.26 \mu \mathrm{g}$ per cow per day.

${ }^{\ddagger}$ For (after-before) being different than zero.

Bertoni (1999). 
The AFB1 is promptly absorbed within the gastrointestinal tract of dairy cows and rapidly transferred as AFM1 into milk (Polan et al., 1974). Milking cows fed a $5 \mathrm{mg}$ AFB1 bolus had detectable blood plasma AFM1 and AFB1 concentrations as soon as $15 \mathrm{~min}$ after treatment, indicating both a rapid absorption of AFB1 through the rumen wall and metabolism into AFM1 (Moschini et al., 2006). The authors in this study used the retinol palmitate plasma level as a marker for intestinal adsorption (Bertoni et al., 2001), which indicated a probable AFB1 absorption at the rumen level and an intestinal contribution to the AFM1 plasma level 120 min after drenching.

The adsorption and consequent transfer to blood and biological fluids is by passive diffusion of the polar component into the liquid phase and by diffusion or active transport of the non-polar component into the lipid phase. Because of their low molecular weight (AFB1 $=312.27$ and AFM1 $=328.27$ formula weight), the toxins are rapidly adsorbed through membranes by a passive mechanism (Yiannikouris and Jouany, 2002). Upon adsorption, the body's ability for AFB1 detoxification is associated with the action of the liver microsomal cytochrome $P$-450 enzyme family and the enzyme S-glutation-transferase (Galtier, 1999). This system is effective within 7 and $351 \mu \mathrm{g}$ per head per day (Munksgaard et al., 1987). The level of AFB1 being used in our trial was lower than $80 \mu \mathrm{g} / \mathrm{kg} \mathrm{BW}$, a threshold value after which a decrease of feed intake was observed in calves (Lynch et al., 1971).

Milk yield was decreased when feeding $100 \mu \mathrm{g} / \mathrm{kg}$ AFB1 (Patterson and Anderson, 1982), and a considerable milk yield reduction was observed in cows fed 100 and $300 \mu \mathrm{g}$ AFB1 per kg BW (Mertens and Wyatt, 1977). Similar results were obtained by Applebaum et al. (1982). The level of AFB1 contamination used in our trial $(0.16 \mu \mathrm{g} / \mathrm{kg}$ BW) was lower than the indicated threshold value of $100 \mu \mathrm{g} / \mathrm{kg} \mathrm{BW}$ for milk yield depression, and no changes in milk yield pattern were observed during the AFB1 ingestion period, as would be expected (Figure 2).

Several factors could affect aflatoxin CO. The variability observed among animals could be related to differences in rumen degradation activity (Westlake et al., 1989), difference

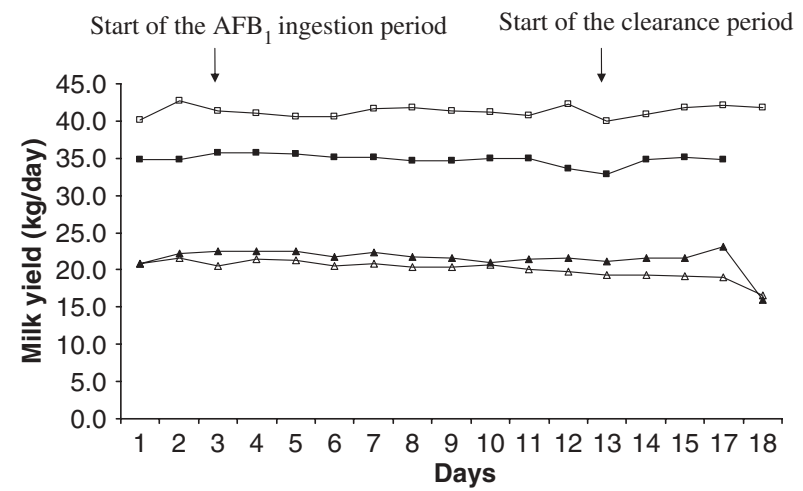

Figure 2 Milk yield of cows from different factorial arrangement: HY-HSCC, ( $\square$ ) HY-LSCC, ( $\mathbf{\Delta})$ LY-HSCC and $(\triangle)$ LY-LSCC. in rumen biotransformation to aflatoxicol and other metabolites other than AFM1 (Auerbach et al., 1998), differences in terms of induction of the enzymatic AFB1 oxidation system (Steiner et al., 1990) and differences in mammary gland permeability (Lafont et al., 1983).

Milk AFM1 content has been previously related to SCC (Lafont et al., 1983). However, more recent work suggests that milk yield is the main factor contributing to the total AFM1 excretion (Pettersson et al., 1989; Veldman et al., 1992). In our trial, the total AFM1 excretion and the CO in milk were affected by the milk yield and not by the SCC during the plateau period (Table 2). These data suggest a higher AFM1 excretion in high-milk-yield cows compared with low-milk-yield cows.

Under the conditions of this experiment, in which all cows received AFB1, and the levels of AFB1 exposure, the relationship between $\mathrm{CO}(\%)$ and milk yield $(\mathrm{kg})$ can be described as follows (Figure 3):

$$
\begin{aligned}
& \mathrm{CO}=- 0.326+0.077 \times \text { milk yield } \\
& \quad\left(\text { residual s.d. }=0.692 ; R^{2}=0.58\right) .
\end{aligned}
$$

The distribution of the residuals outlines the absence of any bias related to the milk yield on $\mathrm{CO}$ estimate. On average, the high-milk-yielding cows had a 1.81-fold increase in the $\mathrm{CO}$ to milk, which is in agreement with previous reported data in early and late lactating dairy cows (Lafont et al., 1983; Veldman et al., 1992). The inappropriate implementation of equations relating $\mathrm{CO}$ and milk yield could lead to erroneous conclusions in terms of maximum AFB1 daily intake to comply with the EU limit of AFM1 in milk. For instance, the plotting of the estimated CO obtained when applying the Veldman et al. (1992) equation to our milk yield against values calculated with our equation clearly indicate the presence of factors not accounted for (source of contamination, animal variability, etc.) in both equations, which limits the equations to their respective trials for CO estimates (Figure 4). A simple steady-state model has been proposed for the disposition of AFB1 and AFM1 in the lactating cow (Van Eijkeren et al., 2006). The

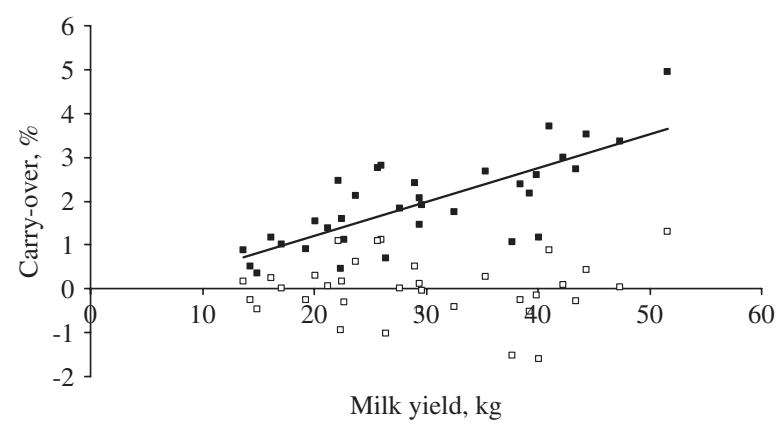

Figure 3 Plot of observed $(\mathbf{\square})$ and residuals $(\square)$ for carryover v. milk yield $(\mathrm{kg})$. Carry over $=-0.326+0.077 \times$ milk yield $(\mathrm{kg})$ (residual s.d. $=0.692, R^{2}=0.58$ ). 


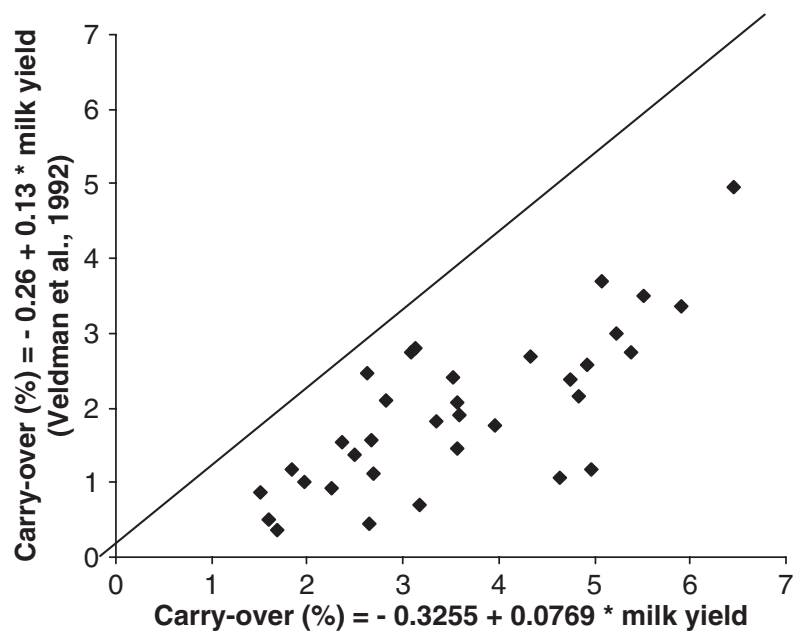

Figure 4 Plot of the predicted carry-over according to the obtained equation $v$. the predicted carry over as proposed by Veldman et al. (1992).

model attempts to better define the kinetics of CO of AFB1 in feed to AFM1 in milk. However, the application of the model to our data did not fit: while daily intake of AFB1 was similar among different milk-yielding groups (LY, HY), the calculated AFM1 concentrations were 1.3- and 0.9-fold the corresponding observed mean levels, respectively, for the LY and HY groups.

Mastitis as measured by high SCC could cause disruption of the tight junction of alveolar cell membranes in the mammary gland. Because of this reduction in the integrity of the blood-udder barrier, an influx of pro-inflammatory factors might further disrupt the tight junction and increased blood-udder permeability (Davis et al., 1999). Similar results were observed in sheep where distended udders related to the pro-inflammatory factors have been found in the milk of sheep under similar circumstances (Colditz, 1988). Furthermore, anti-inflammatory factors from hyper-immunised cows reduced the cell membrane tight junction permeability (Stelwagen et al., 1997).

The animal arrangement for the SCC content in our trial obtained groups (LY-LSCC, HY-LSCC) with average SCC below or slightly over $100000 / \mathrm{ml}$, which is considered a threshold value for a healthy udder (Walstra and Jenness, 1984; Steiner et al., 1990) and groups considerably higher in SCC (LY-HSCC, HY-HSCC) in which the integrity of tight junction was probably damaged allowing leaking of blood and milk components (Bruckmaier et al., 2004).

Thus, factors affecting the permeability of the bloodudder barrier, together with the low AFB1 molecular weight (312.27 formula weight), could regulate the excretion of AFM1 into milk, particularly in high-milk-producing dairy cows. From our data the increased mammary gland permeability as a consequence of inflammatory processes alone does not seem to explain the increase of the $\mathrm{CO}$ (Table 2).

As previously reported (Frobish et al., 1986; Diaz et al., 2004), the AFM1 clearance at the end of the AFB1 ingestion period was fast, bringing the AFM1 below the legislative limit ( $50 \mathrm{ng} / \mathrm{l})$ within $24 \mathrm{~h}$ (all groups) and lower than $15 \mathrm{ng} / \mathrm{l}$ (low somatic cells groups) within $48 \mathrm{~h}$ from the last day of ingestion.

The AFB1 ingestion period did induce changes in some of the evaluated plasma parameters (Table 3). Even though the change in the gamma-glutamyl transferase might suggest a damage of the liver at the cellular level, the values for cows in this study were within the upper limit for cows at their stage of lactation (Bertoni et al., 2000).

\section{Conclusions}

The current data suggest that milk yield is the major factor affecting the total excretion of AFM1. In this study, the CO calculated from a predictive equation was lower than previously reported for similar levels of AFB1 intake, although not outside the range. Previously reported differences in CO associated with membrane permeability due to inflammatory factors were only detectable during the first days of AFB1 ingestion and only occurred in the high-yielding cows on experiment. It is possible that the low molecular weight of aflatoxins could account for the absence of the SCC effect at plateau conditions.

\section{Acknowledgements}

This research was supported by the AFLARID project Ministero delle Politiche Agricole e Forestali (MiPAF - Italy).

\section{References}

Allcroft R, Roberts BA and Lloyd MK 1968. Excretion of aflatoxin in a cow. Food Cosmetics Toxicology 6, 619-625.

Association of Official Analytical Chemists 1995. Preparation of standards for mycotoxins. In Official methods of analysis of the AOAC (ed. KC Helrich), Association of Official Analytical Chemists Inc., Arlington, USA.

Applebaum RS, Brackett RE, Wiseman DW and Marth EH 1982. Responses of dairy cows to dietary aflatoxin: feed intake and yield, toxin content, and quality of milk of cows treated with pure and impure aflatoxin. Journal of Dairy Science 65, 1503-1508.

Auerbach H, Maas RFM, Op den Camp HJM, Pol A and Fink-Gremmels J 1998. Biodegradation of aflatoxin B1 by bovine rumen micro-organism in vitro and its effects on rumen fermentation. Revue de Médicine Vétérinaire 149, 573.

Battacone G, Nudda A, Cannas A, Borlino AC, Bomboi G and Pulina G 2003. Excretion of aflatoxin $M 1$ in milk of dairy ewes treated with different doses of aflatoxin B1. Journal of Dairy Science 86, 2667-2675.

Bertoni G 1999. Guida all'interpretazione dei profili metabolici. Associazione Scientifica di Produzione Animale, Università degli Studi di Perugia.

Bertoni G, Calamari L and Trevisi E 2000. New criteria for identifying reference values for specific blood parameters in dairy cows. La Selezione Veterinaria (Suppl.), S261-S268.

Bertoni G, Trevisi E, Bani P and Xingtai H 2001. Behaviour of digesta passage rate during lactation in primiparous and multiparous dairy cows. In Proceedings of the ASPA XIV Congress, pp. 144-146.

Bruckmaier RM, Weiss D, Wiedemann M, Schmitz S and Wendl G 2004. Changes of physicochemical indicators during mastitis and the effects of milk ejection on their sensitivity. Journal of Dairy Research 71, 316-321.

Colditz IG 1988. Studies on the inflammatory response during involution of the ovine mammary gland. Quarterly Journal of Experimental Physiology 73, 363-368. 
Davis SR, Farr VC and Stelwagen K 1999. Regulation of yield loss and milk composition during once-daily milking: a review. Livestock Production Science 59, 77-94.

Diaz DE, Hagler Jr WM, Blackwelder JT, Eve JA, Hopkins BA, Anderson KL, Jones FT and Whitlow LW 2004. Aflatoxin binders II: Reduction of aflatoxin M1 in milk by sequestering agents of cows consuming aflatoxin in feed. Mycopathologia 157, 233-241.

European Community 1986. 1986/609/EC. Council Directive 86/609/EC of 24 November 1986 on the approximation of laws, regulations and administrative provisions of the Member States regarding the protection of animals used for experimental and other scientific purposes. Official Journal L 358, 1-28.

European Community 2003. 2003/100/EC. Commission Directive 2003/100/EC of 31 October 2003 amending Annex I to Directive 2002/32/EC of the European Parliament and of the Council on undesirable substances in animal feed (text with EEA relevance). Official Journal of the European Union L 285, 33-37.

European Community 2006. 2006/1881/EC. Commission Regulation (EC) No $1881 / 2006$ of 19 December 2006 setting maximum levels for certain contaminants in foodstuffs (text with EEA relevance). Official Journal of the European Union L 364, 5-24.

Frobish RA, Bradley BD, Wagner DD, Long-Bradley PE and Hairston H 1986. Aflatoxin residues in milk of dairy cows after ingestion of naturally contaminated grain. Journal of Food Protection 49, 781-785.

Galtier P 1999. Biotransformation and fate of mycotoxins. Journal of Toxicology, Toxin Reviews 18, 295-312.

International Agency for Research on Cancer 2002. Some traditional herbal medicines, some mycotoxins, napthalene and styrene. In IARC monographs on the evaluation of carcinogenic risks to humans, vol. 82, pp. 171-175. IARC, Lyon, France.

Lafont P, Sarfati J, Jacquet J, Gaillardin M and Lafont J 1983. Influences de facteurs pathologiques et nutritionnels sur l'elimination de l'aflatoxine par la memelle chez la vache. Microbiologie Aliments Nutrition 1, 293-300.

Lynch GP, Shalkop WT, Jacoby NM, Smith DF and Miller RW 1971. Response of dairy calves to oral doses of aflatoxin. Journal of Dairy Science 54, 1687-1698.

Mortimer DN, Gilbert J and Shepherd MJ 1987. Rapid and highly sensitive analysis of aflatoxin M1 in liquid and powdered milks using an affinity column cleanup. Journal of Chromatography 407, 393-398.

Mertens DR 1997. Creating a system for meeting the fiber requirements of dairy cows. Journal of Dairy Science 80, 1463-1481.

Mertens DR and Wyatt RD 1977. Acute aflatoxicosis in lactating dairy cows. Journal of Dairy Science 60, 153-154.

Moschini M, Masoero F, Diaz DE, Gallo A, Pietri A and Piva G 2006. Plasma aflatoxin concentrations over time in bolus fed lactating dairy cows. Journal of Animal Science 84 (Suppl. 1), 74.

Munksgaard L, Larsen J, Werner H, Andersen PE and Viuf BT 1987. Carry over of aflatoxin from cows' feed to milk and milk products. Milchwissenschaft 42, 165-167.
National Research Council 2001. Nutrient requirements of dairy cattle, seventh revised edition. National Academy of Science, Washington, DC.

Patterson DSP and Anderson PH 1982. Recent aflatoxin feeding experiments in cattle. Veterinary Record 110, 60.

Pettersson H, Bertilsson J and Wennberg 0 1989. Carry-over of aflatoxin from dairy cattle feed to milk. Healthy animals, safe foods, healthy man. World association of veterinary food hygienists $X$ th jubilee international symposium, pp. 97-102.

Polan CE, Hayes JR and Campbell TC 1974. Consumption and fate of aflatoxin B1 by lactating cows. Journal of Agricultural and Food Chemistry 22, 635-638.

Statistical Analysis System Institute 1999-2001. SAS/STAT user's guide: statistics, version 8.2. Statistical Analysis Systems Institute Inc., Cary, NC.

Steiner J, Bluthgen A and Heeschen WWSHJ 1990. Untersuchungen zur beeinflussung der ausscheidung von aflatoxin M1 durch polychlorierte bifhenyle beim laktierenden rind. Kieler Milchwirtschaftliche Forsungberichte $42,543-552$.

Stelwagen K, Farr VC, McFadden HA, Prosser CG and Davis SR 1997. Time course of milk accumulation-induced opening of mammary tight junctions, and blood clearance of milk components. American Journal of Physiology 273, R379-R386.

Trucksess MW, Richard JL, Stoloff L, McDonald JS and Brumley WC 1983. Absorption and distribution patterns of aflatoxicol and aflatoxins B1 and M1 in blood and milk of cows given aflatoxin B1. American Journal of Veterinary Research 44, 1753-1756.

Van Egmond HP 1989. Aflatoxin M1: occurrence, toxicity, regulation. In Mycotoxins in dairy products (ed. HP van Egmond), pp. 11-55. Elsevier Applied Science, London, UK.

Van Eijkeren JCH, Bakker MI and Zeilmaker MJ 2006. A simple steadystate model for carry-over of aflatoxins from feed to cow's milk. Food Additives and Contaminants 23, 833-838.

Van Soest PJ, Robertson JB and Lewis BA 1991. Methods for dietary fiber neutral detergent fiber, and nonstarch polysaccharides in relation to animal nutrition. Journal of Dairy Science 74, 3583-3597.

Veldman A, Meijs JAC, Borggreve GJ and Heeres van der Tol JJ 1992. Carry-over of aflatoxin from cows' food to milk. Animal Production 55 163-168.

Walstra P and Jenness R 1984. Variability. In Dairy chemistry and physics (ed. P Walstra and R Jenness), A Wiley-Interscience Publication, John Wiley \& Sons, Inc., New York.

Westlake K, Mackie RI and Dutton MF 1989. In vitro metabolism of mycotoxins by bacterial, protozoal and ovine ruminal fluid preparations. Animal Feed Science and Technology 25, 169-178.

Yiannikouris A and Jouany JP 2002. Mycotoxins in feeds and their fate in animals: a review. Animal Research 51, 81-99. 